\title{
Powder and Solvent for Epilesional Solution Dosage Form
}

National Cancer Institute

\section{Source}

National Cancer Institute. Powder and Solvent for Epilesional Solution Dosage Form. NCI

Thesaurus. Code C149782.

Sterile powder and sterile solvent intended for the preparation of an epilesional solution by dissolving the powder in the solvent. 